\title{
Shifting Urban Freight Deliveries to the Off-Peak Hours: A Review of Theory and Practice
}

\author{
IVÁN SÁNCHEZ-DÍAZ", PETER GEOREN**, MÄRTA BROLINSON ${ }^{*}$
}

${ }^{*}$ Chalmers University of Technology, Vera Sanbergs Allé 8, Gothenburg, 412 96, Sweden. Phone: +4607-21585-593. Email: ivan.sanchez@chalmers.se

${ }^{* *}$ KTH Royal Institute of Technology, Brinellvägen 83, Stockholm, 114 27, Sweden. Phone: +4607-06949-563. E-mail: peterg@kth.se

${ }^{\dagger}$ City of Stockholm, Fleming 4, Stockholm, 112 26, Sweden. Phone: +4608-508-27-200. E-mail:

marta.brolinson@stockholm.se

ACKNOWLEDGEMENT This research was supported by the Fordonsstrategisk Forskning och Innovation (FFI) Program under "Off-Peak City Distribution" Project, Grant 2014-05598. This support is both acknowledged and appreciated. The authors would like to acknowledge the support from the interviews' participants: Stacey Hodge from NYCDOT, Jaz Chani from Transport for London, Martin Hellung-Larsen from Trafikstyrelsen, and Eric Devin from Cemafroid. The authors would also like to acknowledge the contributions from the Integrated Transport Research Lab (ITRL) at KTH. This paper does not represent the official position of the funding agency or the organizations whose representatives participated in the interviews.

\begin{abstract}
This paper presents a comprehensive review of the literature on off-peak hour deliveries (OPHD). The review identifies different approaches and policy levers used in the past, such as the laissez-faire approach, a road pricing approach, an incentives approach, and a regulatory approach. The paper also identifies different delivery reception schemes discussed in the literature. The authors complement the theory with a synthesis of pilot tests and the analysis of a set of interviews with practitioners (from the public sector and other organizations) in charge of OPHD programs. The results from this review show the potential benefits that these programs could bring about, the challenges faced in the early stages - along with potential solutions - and the significant progress that has been made in this domain in the last decade. According to the review, the results from the pilot tests tend to be positive, suggesting the importance of these programs to reach more efficient and sustainable transportation systems.
\end{abstract}

KEYWORDS off-peak hour deliveries, freight transportation policy, urban freight transportation, freight efficiency, nighttime freight distribution

\section{Introduction}

The increasing urbanization and the ensuing difficulties to deal with passenger and freight transportation needs have led the public sector and the transportation community to seek for alternatives that alleviate traffic impacts while coping with budget and space constraints. Doing so requires to complement infrastructureoriented solutions with traffic management, logistics interventions, parking management, pricing initiatives, and demand management solutions, among others (Holguín Veras et al., 2015). In particular, it is evident that densely populated cities suffer from an oversaturated infrastructure during daytime hours, but the same space is then sub-utilized during the evening, at night or in the early morning, in the so called Off-Peak Hours $(\mathrm{OPH})$. This reality motivated initiatives to shift urban freight distribution to the $\mathrm{OPH}$ to improve the utilization of existing infrastructure and enhance the efficiency of goods distribution. The definition of off- 
peak hour deliveries (OPHD) often assumes OPH are nighttime or early morning hours, but there is no consensus in the literature about the times covered. The reason for this lack of consensus is that times with high demand for infrastructure (i.e., roads, loading spaces, and sidewalks) vary across cities. Cities with heavy traffic tend to have prolonged peak-hours that cover the entire day, while for other cities peak-hours only cover a few hours. The definition of OPH often depend on noise emission standards or businesses' open hours, and can include both week and weekend days. For instance, while for New York City (NYC), OPH cover from 7PM to 6AM (Holguín-Veras et al., 2013), for Paris they cover from 10PM to 5AM (Club Décibel Villes, 2013), for Denmark OPH are divided between night (6PM to 10PM) and morning (10PM to 7AM) because noise regulations are different for these two periods of time (Kolstrup K. et al., 2014), and for the Ports of Long Beach and Los Angeles OPH also include the weekends (PierPASS, 2007). This definition is pragmatic, but it can influence the assessment of the benefits from moving freight distribution to those times because travel time savings, noise and environmental impacts and receivers' staff costs are larger at midnight than right after business hours.

Although shifting freight distribution to OPH has been tried via congestion pricing and traffic restrictions, the most successful scheme is via OPHD programs, which is the main focus of this paper. OPHD are programs, often led by the public sector, aiming at retiming deliveries from the regular hours to the OPH. The concept of OPHD has been tried in different ways and at different points in time. As described by HolguínVeras (2008), the first documented implementation of OPHD dates from the time of Julius Caesar, who promulgated the Lex Juliana Municipalis to prohibit all deliveries in Rome during the daytime, and allowing them only during the evening. Experiments and regulation to foster OPHD have, since then, been implemented in numerous cities, with the most recent and representatives ones being the one in NYC, implemented in the early 1970s as a traffic control measure (Noel, 1983), and then DeliverEASE implemented since 2006 as an incentive-based program (Holguín-Veras et al., 2013), the Operation "Moondrop" in London in 1968 (Churchill, 1970) and then the experiment during the 2012 Olympic games (Olympic Delivery Authority, 2010), the Night Deliveries program in Paris that is taking place since 2009 (Devin et al., 2014), and the Night Deliveries program in Barcelona that started in 2003 (NICHES, 2008).

There is a general agreement in the literature that successful OPHD programs can (i) improve traffic conditions and lower travel times for road users during daytime hours, (ii) decrease environmental impacts, (iii) increase competitiveness for transportation companies, (iv) increase deliveries reliability for receivers, (v) increase safety by reducing the conflicts between trucks, passenger cars, cyclers and pedestrians, and (vi) enhance a city's livability and attractiveness (Greenzeback et al., 1991, Cambridge Systematics Inc., 1988, Noel, 1983, Holguín-Veras, 2008, Freight Transport Association, 2008, Campbell, 1995, Club Décibel Villes, 2013, Churchill, 1970). For instance, Holguín-Veras et al. (2011) estimate that a full implementation of OPHD in NYC could produce gains in productivity to the freight industry, travel time and environmental savings for all road users corresponding to a benefit of $\$ 147$ to $\$ 193$ million per year. This value would be larger than the expected benefit from other large transportation projects, such as, extending the PATH rapid transit railroad from Lower Manhattan to the Newark Airport, or extending NYC's subway line 7 to run west until West $33^{\text {rd }}$ Street and $11^{\text {th }}$ Avenue (Berechman and Paaswell, 2005). Along with the potential benefits of OPHD, both theory and practice have exposed a number of concerns and obstacles worth of study, such as implementation challenges, potential cost increases for receivers, risks of higher environmental impacts at night, among others (Quak and de Koster, 2007, Holguín-Veras, 2008, Sathaye et al., 2010, Holguín-Veras et al., 2014c, Lammgård and Browne, 2012). 
This paper reviews the literature on OPHD, describes the main experiences with OPHD and analyzes them using a structured approach. To this effect, the authors start by describing the factors affecting delivery time decisions and identifying implementation approaches to shift freight traffic to the $\mathrm{OPH}$, then discuss alternative schemes of OPHD programs, present the OPHD experience in some selected cities, discuss a set of interviews with public sector representatives that led OPHD pilots, and finalize with a conclusion. This review provides a comprehensive picture of OPHD programs to gain knowledge both from successful and less successful initiatives and provide insight for public sector representatives, researchers and practitioners interested in OPHD.

\section{Urban freight stakeholders and delivery-time decision making}

The freight system consists of multiple components that enable to bring the goods from a place of production to the place of consumption. The last leg of this goods movement takes place in cities, where the biggest problems are the lack of space and the interaction of multiple actors that have different interests. In the literature, all the actors that are affected or involved in the movement of goods are referred to as freight stakeholders. Freight stakeholders include producers and sellers of goods, which in the context of transportation are referred to as shippers and receivers; transportation suppliers referred to as carriers; consumers of goods which are also part of the community; the public sector that seeks to maintain an efficient freight system while ensuring the wellbeing of the citizens; and real state agencies that develop and own the facilities where goods are produced and stored, among others. The attributes of freight movements, such as the type of freight vehicles, time-of-the-day when they circulate, and the payload factor are determined by the interactions between stakeholders. Typically, shippers agree delivering conditions with receivers of the goods and then negotiates with a carrier to fulfill those conditions. In cities, most carriers are less-than-truckload companies that can be part of the shipping company, or can be for-hire carriers (either part of a 3PL service or exclusively offering the transportation service). This distinction is important because while private carriers seek to minimize the costs on the whole supply chain, for-hire carriers care exclusively about transportation/logistics costs.

Inducing a shift of freight traffic to the OPH effectively requires to identify the factors influencing deliverytime and understanding the process underlying delivery-time agreements between stakeholders. The key factors identified in the literature include (i) the location of the receiver that restraints delivery-times due to access regulation, building management rules or (un)loading restrictions (Muñuzuri et al., 2012, Allen et al., 2000), (ii) the type of delivery classified as core goods deliveries which are crucial for the normal operations of the receiver or ancillary deliveries (Cherrett et al., 2012), (iii) the commercial activity of the receiver that influences the time-sensitivity of some deliveries (e.g., a bakery cannot start operation without daily early bread deliveries) and the hours at which the establishment accept deliveries (e.g., open hours, access during non-business hours) (Allen et al., 2000), and (iv) the type of carrier (e.g., a single chain, for-hire/own-account transport) that determines whether delivery-time is decided by a central function optimizing overall firms' operations or an outcome of the interaction between shipper, carrier and receiver (Holguín-Veras, 2008). Overall, these factors can be grouped under three dimensions affecting delivery-time: a receiving dimension which determines a primary time-window depending on location and establishments' receiving constraints, a business nature dimension which determines a secondary time-window for core deliveries based on their time-sensitivity for the receiver, and an operational dimension which influences delivery-time depending on the type of carrier, the type of delivery, routing efficiency and other external factors. 
The receiving and the business nature dimensions define time-windows constraints that are very difficult to modify without the consent of receivers and thus are often part of a formal/unformal delivery agreement between receiver and carrier. Unfortunately, these time-windows tend to overlap with peak-hours. The operational dimension is dominated by the carrier and, as long as it respects the time-windows set by the two other dimensions, the specific delivery-time may or may not be agreed with the receiver. The latter is often the case for most ancillary deliveries, for independent receivers that have multiple vendors and a decentralized supply system, and for offices and residential deliveries (Allen et al., 2000). As will be shown in the next section, the public sector approach to induce OPHD is highly dependent on the targeted dimension.

\section{Implementation approaches: Different perspectives adopted by the public sector to induce OPHD}

The literature shows multiple approaches to induce a shift of freight traffic to the OPH. Cities have used various measures to foster this shift, mainly by charging carriers, managing loading zones or by fostering the retiming of urban deliveries, with more or less success. The implementation approach — defined in this paper as the set of measures and policy levers used to foster a shift of freight traffic to the OPH-for each city is highly influenced by local traditional practices, stakeholders' attitude toward regulation, the legal framework, and the interactions between freight stakeholders. Measures that may be valid in some cities, such as, the daytime bans in Shanghai may not be feasible i Dndon.

The implementation approaches identified in this review cover a wide spectrum ranging from marketoriented approaches, such as, a laissez-faire approach, congestion pricing strategies, and incentives-based voluntary programs, to more regulatory-oriented approaches, such as, allowing access during OPH but introducing (or enforcing existing) regulation for noise levels, regulating the use of (un)loading bays during certain hours, and daytime bans that oblige carriers to deliver at night.

\subsection{Laissez faire approach}

Most transportation strategic plans focus on passengers' transportation and leave to the private sector the task of optimizing their urban freight distribution. This can result from a lack of knowledge about the freight system, or simply a deliberate decision. In this context, a laissez-faire approach, assumes that the freight transportation market finds the most efficient outcome and thus there is no need from the public sector to interfere. This was, for instance, the conclusion from an early study on OPHD that used data from different cities in the USA (Organization for Environmental Growth Inc. and Federal Highway Administration, 1979).

Noel et al. (1980) identified some commercial sectors in NYC that did OPHD as part of their normal business operations, i.e., delivery-time decision making converged to the OPH. These sectors include dairy products distribution, moving services, trucking services, garbage collection, oil distribution, newspaper distribution, bakery services, grocery stores, and beverage industries. However, there is evidence showing that in the absence of a program, the percentage of deliveries taking place during the $\mathrm{OPH}$ is too small to alleviate traffic conditions during the peak-hours. Vilain and Wolfrom (2000) found that in 1998 less than 5\% of the trucks entering Manhattan did it during the OPH. In Amsterdam, Schoemaker et al. (2006) estimated that about $11 \%$ of deliveries take place during OPH; while Allen et al. (2008) analyzed different surveys in the UK made between 1999 and 2007 and found that less than 5\% of the deliveries took place during OPH (there is no specific mention of any OPH regulation in place). In essence, this low percentage of OPHD reveal that despite its potential benefits, current conditions favor urban deliveries during the regular hours. This fact has 
been observed by public authorities around the world who started to seek for initiatives, typically popular on passenger transportation, which could be adapted to freight to foster a shift of the freight traffic to the OPH.

\subsection{Road pricing}

As opposed to laissez-faire, this approach requires a moderate intervention from the public sector (i.e., define a pricing scheme and build the infrastructure to enforce it) to influence the operational dimension and align the private sector interests to the interests that the public sector judges best for society. The rationality is that charging for the use of roads during the peak-hours is an effective way to manage demand and induce a socially optimal use of infrastructure (Vickrey, 1969, De Palma et al., 2005). However, this approach has shown very little success in the case of freight, as both the empirical evidence and the theory suggests the expected shift cannot be reached through pricing (Vilain and Wolfrom, 2000, Holguín-Veras et al., 2005a, Holguín-Veras et al., 2006).

Using a theoretical approach, Holguín-Veras (2008) studied the necessary conditions for freight vehicles to shift operations to the $\mathrm{OPH}$, and concluded that freight road pricing is not an effective mechanism in competitive markets. The reason is that introducing OPHD requires an agreement between shippers, carriers and receivers (who have to relax their receiving constraints); but carriers have great difficulty in passing the price signal to their receivers, and when the price signal is passed to receivers, it is too weak to offset their costs to accept OPHD. These premises are in line with the empirical evidence from NYC and London.

In NYC, Vilain and Wolfrom (2000) found that despite the tolls increase during peak-hours, most freight vehicles continued entering Manhattan during the peak-hours with a slight spread among OPH. According to the authors a possible explanation is that, as the tolls account for about 10 to 30 percent of the generalized cost of travel, this increase in the tolls - often assumed by the shippers - is not sufficient to persuade shippers to ask their receivers to accept OPHD. Holguín-Veras et al. (2006) also studied the effect of pricing on freight traffic entering Manhattan, and found that an increase in the toll by about 40-50\% during peak-hours did not produce any significant change on freight traffic.

Similar results were found in London, where congestion pricing was implemented in 2003. Broaddus et al. (2015) showed that although the introduction of congestion pricing diverted about $10 \%$ of light freight vehicles to other routes, the amount of inbound freight vehicles remained stable even after the charge increased between 2005 and 2011 from $£ 5$ to $£ 10$. The authors attribute this inelastic behavior to the charge being minor compared to the costs of drivers, labor, and fuel. Paradoxically, the introduction of congestion pricing could even encourage carriers to continue traveling during peak-hours because of the travel time savings accrued from reduction in passenger traffic - which given the high value of time of trucks offsets the congestion pricing - and the increase in reliability. This is not necessarily a negative outcome, but reveals the limited effectiveness of pricing initiatives to induce OPHD. Moreover, this could also affect other objectives pursued by OPHD, such as increasing pedestrians and cyclists' safety.

In essence, as the receiving and business nature constraints are not addressed, using road pricing does not induce a significant shift of freight traffic to OPH. However, it could be an attractive measure to collect funds to finance other complementary measures. For instance, Holguín-Veras and Aros-Vera (2014) suggest to use the money collected to fund an incentive program aimed at inducing receivers' participation in OPHD.

\subsection{Public sector incentives and voluntary participation}


This approach is similar to road pricing in the sense of providing an economic incentive to align private and public interests; but instead of penalizing carriers driving during peak-hours, it seeks to relax receivers' constraints by rewarding voluntary participation in OPHD.

As accepting OPHD can increase staff costs for receivers or increase risks in the case of unassisted OPHD, Holguín-Veras (2008) argues it is necessary that the public sector develops incentive programs to induce receivers to accept OPHD. To increase the effectiveness of these programs, some authors have conducted behavioral research on the type and level of incentives that could induce a change on receivers, and to identify industry sectors that could be more willing to accept OPHD (Domínguez et al., 2012, Holguín-Veras et al., 2007, Holguín-Veras et al., 2015). Holguín-Veras et al. (2014b) summarize the findings from this behavioral research and conclude that food and beverage stores, press and books, clothing stores, apparel manufacturing and accommodation establishments are more inclined to accept OPHD. In terms of incentives, the monetary ones (i.e., tax deduction and one-time incentive) are more effective in fostering acceptance of OPHD. For non-monetary incentives, having a trusted vendor (i.e., the receiver has a relationship of trust with the vendor and the carrier) is the most effective incentive, followed by receiving a discount on shipping costs, receiving public recognition and having business support from the public sector (i.e., provide support services for administrative procedures, legal aspects, and financial/tax implications). Some other factors such as having an external warehouse or being located alone in the facility also favor participation in OPHD. The analyses done by Holguín-Veras et al. (2015) show that the right combination of incentives can increase the overall acceptance of OPHD by receivers from about $5 \%$ to $40 \%$.

Gaining the receivers' support through a number of incentives was the approach of the DeliverEASE program implemented in NYC (Holguín-Veras et al., 2013). The pilot at the origin of this program started in 2003, the implementation phase of the program was launched in June 2011 and, although the research project concluded in September 2013, the implementation is still ongoing. The project area covered Midtown and Lower Manhattan, which includes a number of Business Improvement Districts (i.e., areas where the local businesses pay an additional tax to fund a nonprofit entity that takes measures to enhance the area) that were instrumental to the success of the program. Although the program offered a financial incentive of \$2 000 to the receivers that shifted multiple deliveries to the OPH during at least 6 months, for large companies this incentive was not always needed (Holguín-Veras et al., 2011). According to Holguín-Veras et al. (2011), 90\% of the receivers continued doing unassisted OPHD after the 6 months covered by the incentive, and some of them were coordinating with their vendors to increase the number of OPHD.

Another interesting case where the public sector fostered OPHD through receivers is the London Olympic and Paralympic Games. Before the games, Transport for London coordinated with multiple municipalities and jurisdictions to allow OPHD, and recommended the receivers to accept OPHD as a way to overcome the multiple disruptions that would result from the games (e.g., unreliability of deliveries, diminished accessibility, difficulties for on-street loading/unloading due to the Games restrictions) (Freight Transport Association, 2011, Browne et al., 2014). The surveys done after the Games, showed that implementing OPHD was a successful measure with about 50\% of the respondents accepting OPHD during the event (Transport for London, 2012c). A similar initiative has taken place for the Toronto Pan American Games, where fostering OPHD was one of the strategies to decrease the impacts of the Games on urban freight and on commercial activities. These cases show that disruptive events can also be an incentive for receivers to accept OPHD. Along with these receiver-focused efforts, the public sector has studied different ways to relax access restrictions.

\subsection{Access restrictions and selective relaxation}


Access restrictions is a resource used by local authorities to alleviate overwhelming problems. Ironically, they have been used in two very different ways, either to ban freight vehicles from peak-hours or to ban freight vehicles from $\mathrm{OPH}$.

On the one hand, some cities have implemented daytime bans for freight vehicles as a response to high levels of congestion (e.g., Julius Caesar in Rome), as a measure to alleviate the impacts of disruptive events (e.g., Beijing Olympic Games), or as measure to lessen environmental impacts (e.g., Beijing, Shenzhen and Changsha) (Changsha Bureau of Public Security, 2013, Beijing Traffic Management Bureau, 2014, Shenzhen Bureau of Public Security, 2013, Gang, 2009, Campbell, 1995). However, their implementation have resulted in significant violations of the bans, opposition from receivers who see their business affected by not being able to receive their deliveries when they need them, and increased uncontrolled noise complaints from the citizens (Holguín-Veras et al., 2014a, Campbell, 1995).

On the other hand, numerous cities have in place nighttime city access restriction and regulations that prevent deliveries at night to avoid noise and other impacts on local residents (Browne et al., 2008, London Councils, 2010, Browne et al., 2006). These bans have often resulted from local communities and real state owners' pressure that see freight traffic as a problem for the city's livability. For instance, the City of London and the London's borough councils introduced the London Lorry Control Scheme (LLCS) in 1986, a regulation to restrict the entry of heavy vehicles during the $\mathrm{OPH}$ to help minimizing noise pollution in residential areas during unsocial hours (London Councils, 2010). The LLCS scheme bans the access of freight vehicles with a gross weight over 18 tonnes during the OPH (i.e., from 9PM to 7AM on weekdays, and from 1PM on Saturday to 7AM on Monday) on the restricted roads, which represent most roads in the network (London Councils, 2010, Browne et al., 2007). According to the Freight Transport Association (FTA), the annual operative cost caused by the diversions to comply with the LLCS is about $£ 30$ million (Freight Transport Association). Although this regulation does not apply for freight vehicles under 18 tonnes, which can circulate in the network during the $\mathrm{OPH}$, there are several delivery restrictions in place due to planning conditions, noise abatement notices or local agreements between retailers, the local authority and local residents (Transport for London, 2012a).

Given the potential benefits of implementing OPHD, local authorities have in the last decade started to assess the impacts of relaxing access restrictions for vehicles that meet noise emissions standards. This has been the main approach of European OPHD pilots. An important project that opened the possibility of doing OPHD while observing noise standards is the PIEK program originated in the Netherlands (Goevaers, 2011, Goevaers, 2010). The PIEK certification scheme developed a set of measurements standards, low-noise practices and equipment to comply with operating under $60 \mathrm{~dB}(\mathrm{~A})$ and make possible OPHD. The PIEKstandard has been implemented across several European countries (e.g., UK, France, Belgium) to facilitate OPHD (Goevaers, 2011).

In general, the selective relaxation approach includes a set of pilot tests to assess the feasibility of OPHD, and a strong stakeholder engagement process to ensure that the benefits are perceived by every stakeholder and the obstacles are properly solved. In England, the Department for Transport, the FTA and the Noise Abatement Society (NAS) established the Quiet Deliveries Demonstration Scheme (QDDS) in 2009 to lead different pilot tests across England and formulate a set of guidelines to improve OPHD practices, implement OPHD without disturbing local residents and foster a relaxation of the bans (Freight Transport Association, 2008). These efforts facilitated the later implementation of OPHD during the London 2012 Games, and the Retiming Program that is currently in place (Transport for London, 2015). 
In Paris, a group of community representatives worked together with Cemafroid (center of experts for cold supply chains), the Demeter Club for the Environment and Logistics and with France Nature Environment to create the Certibruit association (Club Décibel Villes, 2013). In 2011, this association created the label Certibruit to certify the efforts from restaurants and commercial establishments that respect the standards allowing to do OPHD without noise impacts. The Certibruit label ensures that businesses doing and receiving OPHD use PIEK-certified engines, have staff trained to do deliveries respecting low noise standards, and have establishments and loading zones with acoustic treatments to decrease noise impacts (Club Décibel Villes, 2013, Devin et al., 2014). Given the success of the trials, the OPHD project is now included in the Plan of the City of Paris as one of the initiatives to reach sustainable urban logistics (The City of Paris, 2013).

Similar approaches have been tried in Barcelona (Spain), Dublin (Ireland), Stockholm (Sweden) and across Denmark (Kolstrup K. et al., 2014, Trafikstyrelsen and Vaeksthus, 2014, NICHES, 2008, Institut Cerdá, 2010). In those cases, truck drivers are trained in practices to diminish noise and low noise technology (both engines and carry equipment) is tested under the PIEK standards, while monitoring that the residents of the area are not disturbed and do not issue any noise complaint.

\section{OPHD schemes: The challenge of receiving during non-business hours}

Another important aspect of the successful implementation of OPHD is the way in which delivery operations occur. This review identified three main schemes under which OPHD take place: staffed OPHD, unassisted OPHD, and OPHD coordinated by facility managers in large traffic generators. The cost, the risk, and the reliability of OPHD depend significantly on the scheme selected.

\subsection{Staffed OPHD}

Most OPHD operations have staff from receiving establishment present to verify and accept the deliveries as a way to minimize the risk of accidental damages, errors in deliveries, and the risk of lost products (HolguínVeras et al., 2012). Under some schemes, store managers are also required to supervise OPHD to decrease risks (Churchill, 1970). Staffed OPHD can be scheduled within a short time window before or after business hours which entails extended hours for the staff, or at any time during the OPH which entails a new shift. Although schemes where receivers extend their hours have lower costs, they also impose additional constraints to the carriers who will not have time to depart from the warehouse during the $\mathrm{OPH}$ and deliver to all the customers within the time window, leading to a lack of reliability that can put the program in jeopardy. For instance, the burden on the staff and the lack of reliability were some reasons explaining the failure of the Operation "Moondrop” program tested in London in 1966 (Churchill, 1970).

In the case of integrated carrier-receiver operations, the extra costs associated with the new shift or the extended hours for the staff can be partly offset with the savings from driving during the OPH (HolguínVeras, 2008). For independent carrier-receiver operations, the extra labor costs incurred by receivers deter them from participating in OPHD programs. In general, the benefits from OPHD for independent receivers (i.e., more reliable deliveries, less interruptions during business hours, and less delivery traffic conflicting with customers) are not enough to cover the extra labor costs (Churchill, 1970). As discussed in Section 2, the public sector can offer an incentive to receivers that participate in OPHD. However, even if a monetary onetime incentive can be effective to persuade receivers to participate in the pilot, it may not be enough to maintain them on the OPHD program after the pilot, unless an on-going incentive is offered to compensate for the extra labor cost, which would place a burden on the public sector funding the program (Holguín-Veras et al., 2014b). 


\subsection{Unassisted OPHD}

Unassisted OPHD refer to the cases where receivers allow their vendors to enter the premises and deliver with no staff present (Holguín-Veras et al., 2015). This scheme is particularly appealing for integrated carriers-receivers operations where the goods are supplied by a parent company, or where there is a long lasting relationship of trust between the receiver and the carrier. Unassisted OPHD can be implemented under different schemes, including (i) a full access where the receiver gives the key of the establishment to the carrier, (ii) a controlled access in which the receiver designates an area for unloading (e.g., virtual cages, a refrigerator) and uses a laser system and cameras to enforce it, and (iii) a separate access in which the receiver provides a delivery locker outside of the establishment or has double doors to separate the delivery area from the rest of the premises (Ogden, 1992, Holguín-Veras et al., 2012). Holguín-Veras et al. (2012) provide an analysis of the tradeoffs between risk and cost for the different OPHD schemes and technologies supporting them, and concludes that the most appropriate choice depend mainly on the relationship between carrier and receiver, the risk and cost the receiver is willing to assume, the type of commodity being handled, the size of the deliveries and the type of technology available for the receiver.

As discussed by Holguín-Veras et al. (2011), the NYC pilot suggested that the feasibility of the unassisted scheme was crucial because it opened the doors for OPHD programs without on-going incentives. The pilot was designed with about half of participants doing staffed OPHD and half doing unassisted OPHD (HolguínVeras et al., 2011). While for the receivers doing staffed OPHD most of the incentive was used to pay for the extra staff costs; for the receivers doing unassisted OPHD the incentive became a profit. Once the pilot ended, the receivers with staffed OPHD returned to the regular hours, but about $90 \%$ of the receivers doing unassisted OPHD decided to continue OPHD. The follow-up interviews to those receivers revealed that they decided to continue doing unassisted OPHD, because of the convenience and the higher reliability of deliveries (when the establishment opens they know their supplies are there) which in some cases even allowed them to reduce inventories (Holguín-Veras et al., 2015).

Unassisted OPHD have also been implemented in Denmark and in Paris (France). During the pilot tests in Denmark, the stores owners granted access to fresh bread distributors to their premises or to a box in front of the establishments (Kolstrup K. et al., 2014). In the case of France, libraries receiving their books during the OPH give a key to their carriers (Syndicat de la Librairie Française, 2009).

\subsection{OPHD at large traffic generators}

Commercial facilities housing numerous commercial establishments that collectively generate vast amounts of freight trips (e.g., large buildings, malls), or facilities hosting activities that generate a significant freight traffic (universities, sports complexes, ports) are referred to as large traffic generators in the literature (Jaller et al., 2014, Holguín-Veras et al., 2005b). Holguín-Veras et al. (2011) show that large traffic generators are a convenient target for OPHD because the manager offers a channel to coordinate deliveries, and the facilities tend to be well equipped to receive both staffed and unassisted OPHD (they have delivery rooms, security staff or cameras at night, and staff prices can be shared among multiple businesses) so that the individual establishments can continue receive their deliveries during the regular hours without incurring in significant additional costs. Moreover, engaging the facility owners (e.g., real estate agents, the public sector) can be easier because the owners are interested in the attractiveness of the area; and very effective because, as they generate large amounts of traffic - 4\% of all freight traffic in Manhattan according to Jaller et al. (2014)-, the implementation efforts have a larger payoff (Holguín-Veras et al., 2013). 
Some large traffic generators that have successfully implemented OPHD include the Waldorf Astoria Hotel and Grand Station in NYC, and the Ports of Long Beach and Los Angeles. The Waldorf Astoria and Grand Station implemented OPHD as part of the pilot and following implementation of the OPHD project in NYC. The Ports of Long Beach and Los Angeles started to shift their truck traffic to the OPH as part of the OffPeak program created and implemented by PierPASS. To foster the OffPeak program, a $\$ 40$ fee was charged for each twenty-feet-equivalent unit (TEU) transported during peak-hours, starting in April 2006. The program was very successful, and by September 2014 the program completed 30 million truck trips handled during the OPH since its start, about 17,000 truck trips are handled on a typical night (PierPASS, 2007). Other type of large traffic generators where OPHD feasibility has not been thoroughly studied are large shopping malls, schools and Universities.

\section{$5 \quad$ Pilot tests: The leap from theory to practice}

As shown in the previous sections, there is a body of literature discussing the concept of OPHD. This section provides a synthesis of selected pilot tests that have taken placed during the last decade across North America and Europe (geographic scope of this study). The pilot tests in this review were selected such that: both large and medium size-cities are included, testing OPHD is the main objective of the pilots, efficiency gains and environmental savings are measured, and challenges and success factors are analyzed. Some of them were successful and led to the incorporation of OPHD as part of the City's plan, some others were moderately successful as they were accomplished but the program was then archived, and some others were not completed. The objective of having this mix is to provide a broader view of success factors but also potential challenges and risks when pilot testing OPHD. The review is based primarily on the findings reported in papers and technical reports complemented with some interviews with representatives of the organizations that led the tests.

The pilots presented include (i) the test and implementation of the DeliverEASE project in NYC (HolguínVeras, 2006, Holguín-Veras et al., 2013); (ii) the Quiet Deliveries Demonstration Scheme (QDDS) led by the UK Department for Transport, the FTA, and the Noise Abatement Society in 2009 to implement pilots across England and formulate a set of guidelines to facilitate quiet OPHD (Department for Transport, 2011, Freight Transport Association, 2008); (iii) the pilots in preparation for the 2012 London Olympic and Paralympic Games, the implementation during the Games, and the later Retiming Program that started pilots in 2013 to implement OPHD as part of the City's policy (Noise Abatement Society, 2012, Transport for London, 2012b, Transport for London, 2015, Re-timing Deliveries Consortium, 2015); (iv) the pilots that took place during 2012 and 2013 in Denmark to assess the feasibility of OPHD as a response to the private sector demands (Baster H. et al., 2014, Kolstrup K. et al., 2014, Trafikstyrelsen and Vaeksthus, 2014); (v) the pilots from 2012 that led to the creation of Certibruit in Paris (Syndicat de la Librairie Française, 2009, The City of Paris, 2013, Club Décibel Villes, 2013, Devin et al., 2014); and (vi) the pilot currently being implemented in Stockholm. Table 1 provides a summary of characteristics from these pilots. 
Table 1: Summary table for selected OPHD pilots

\begin{tabular}{|c|c|c|c|c|c|c|c|c|c|}
\hline & \multirow[b]{2}{*}{ Pilot test } & \multicolumn{2}{|c|}{ New York City } & \multirow{2}{*}{$\begin{array}{c}\text { England } \\
\text { QDDS } \\
2009\end{array}$} & \multicolumn{2}{|c|}{ London } & \multirow{2}{*}{$\begin{array}{c}\text { Denmark } \\
\text { OPH } \\
\text { Distribu- } \\
\text { tion } 2011\end{array}$} & \multirow{2}{*}{$\begin{array}{c}\text { Paris } \\
\text { NTD } 2012\end{array}$} & \multirow{2}{*}{$\begin{array}{c}\text { Stockholm } \\
\text { OPHD } \\
2015\end{array}$} \\
\hline & & $\begin{array}{l}\text { OHD } \\
2003\end{array}$ & $\begin{array}{c}\text { Deliver- } \\
\text { EASE } \\
2010 \\
\end{array}$ & & $\begin{array}{c}\text { Pre- } \\
\text { Games } \\
2012\end{array}$ & $\begin{array}{l}\text { Retiming } \\
2013\end{array}$ & & & \\
\hline & Length & 6 months & 6 months & 2 years & 3 months & n.a. & 2 years & 6 weeks & 2 years \\
\hline & Scope & $\begin{array}{c}8 \text { carriers, } \\
25 \\
\text { receivers }\end{array}$ & $\begin{array}{l}400 \\
\text { receivers }\end{array}$ & 6 retailers & $\begin{array}{c}\text { All } \\
\text { business } \\
\text { affected }\end{array}$ & $\begin{array}{l}2 \text { major } \\
\text { retailers }\end{array}$ & $\begin{array}{l}1 \text { carrier } \\
\text { and } \\
\text { receivers } \\
\text { per sector }\end{array}$ & \begin{tabular}{|} 
Libraries, \\
8 \\
receivers
\end{tabular} & $\begin{array}{c}2 \text { carriers, } \\
19 \\
\text { receivers }\end{array}$ \\
\hline \multirow{3}{*}{ 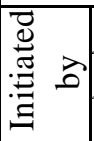 } & Public sector & & & & $\checkmark$ & $\checkmark$ & & $\checkmark$ & $\checkmark$ \\
\hline & University & $\checkmark$ & $\checkmark$ & & & & & & $\checkmark$ \\
\hline & Private sector & & & $\checkmark$ & & $\checkmark$ & $\checkmark$ & & \\
\hline \multirow{4}{*}{ 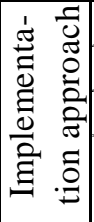 } & Incentives & $\checkmark$ & $\checkmark$ & & & & & & \\
\hline & Laisser faire & & & & & & & & \\
\hline & Ban relaxation & & & $\checkmark$ & $\checkmark$ & $\checkmark$ & $\checkmark$ & $\checkmark$ & $\checkmark$ \\
\hline & $\begin{array}{l}\text { Stakeholder } \\
\text { engagement }\end{array}$ & $\checkmark$ & $\checkmark$ & $\checkmark$ & $\checkmark$ & $\checkmark$ & $\checkmark$ & $\checkmark$ & $\checkmark$ \\
\hline \multirow{3}{*}{ 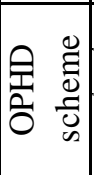 } & Staffed & $\checkmark$ & & $\checkmark$ & $\checkmark$ & $\checkmark$ & $\checkmark$ & $\checkmark$ & $\checkmark$ \\
\hline & Unassisted & $\checkmark$ & $\checkmark$ & & & & $\checkmark$ & $\checkmark$ & $\checkmark$ \\
\hline & $\begin{array}{c}\text { Large Traffic } \\
\text { Generators }\end{array}$ & $\checkmark$ & $\checkmark$ & & & & & & \\
\hline \multirow{10}{*}{ 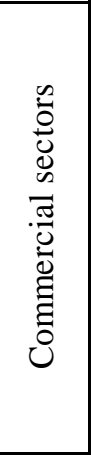 } & Retailers & $\checkmark$ & $\checkmark$ & $\checkmark$ & $\checkmark$ & $\checkmark$ & $\checkmark$ & $\checkmark$ & $\checkmark$ \\
\hline & Food retail & $\checkmark$ & $\checkmark$ & & $\checkmark$ & & $\checkmark$ & $\checkmark$ & $\checkmark$ \\
\hline & Clothes retail & $\checkmark$ & & & & & & & \\
\hline & Pharmacies & & $\checkmark$ & & & & & & \\
\hline & Food services & & $\checkmark$ & & $\checkmark$ & & & $\checkmark$ & $\checkmark$ \\
\hline & Hotels & & $\checkmark$ & & & & & & $\checkmark$ \\
\hline & Flowers & & & & & & $\checkmark$ & & \\
\hline & Beverages & & & & & & $\checkmark$ & & \\
\hline & Libraries & & & & & & & $\checkmark$ & \\
\hline & Other & & & & & & $\checkmark$ & & \\
\hline \multirow{6}{*}{ 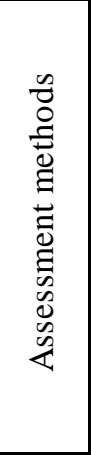 } & $\begin{array}{c}\text { Satisfaction } \\
\text { surveys } \\
\end{array}$ & $\checkmark$ & $\checkmark$ & $\checkmark$ & $\checkmark$ & $\checkmark$ & $\checkmark$ & $\checkmark$ & $\checkmark$ \\
\hline & $\begin{array}{c}\text { Economic } \\
\text { analyses }\end{array}$ & $\checkmark$ & $\checkmark$ & $\checkmark$ & $\checkmark$ & $\checkmark$ & $\checkmark$ & $\checkmark$ & $\checkmark$ \\
\hline & $\begin{array}{c}\text { Noise } \\
\text { measures }\end{array}$ & $\checkmark$ & $\checkmark$ & $\checkmark$ & $\checkmark$ & $\checkmark$ & $\checkmark$ & $\checkmark$ & $\checkmark$ \\
\hline & $\begin{array}{c}\text { Environemen- } \\
\text { tal estimates }\end{array}$ & $\checkmark$ & $\checkmark$ & & $\checkmark$ & $\checkmark$ & $\checkmark$ & $\checkmark$ & $\checkmark$ \\
\hline & GPS measure & $\checkmark$ & $\checkmark$ & & & & $\checkmark$ & & $\checkmark$ \\
\hline & Network & $\checkmark$ & $\checkmark$ & & & & & & \\
\hline \multirow{4}{*}{ 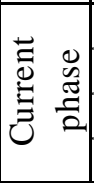 } & In progress & & & & & $\checkmark$ & & & $\checkmark$ \\
\hline & Completed & $\checkmark$ & $\checkmark$ & $\checkmark$ & $\checkmark$ & & $\checkmark$ & $\checkmark$ & \\
\hline & Archived & & & & & & $\checkmark$ & & \\
\hline & City policy & & $\checkmark$ & & & $\checkmark$ & & $\checkmark$ & \\
\hline
\end{tabular}


Sources: Authors' interpretation from results in (Holguín-Veras, 2006, Holguín-Veras et al., 2013, Department for Transport, 2011, Freight Transport Association, 2008, Noise Abatement Society, 2012, Transport for London, 2012b, Transport for London, 2015, Re-timing Deliveries Consortium, 2015, Baster H. et al., 2014, Kolstrup K. et al., 2014, Trafikstyrelsen and Vaeksthus, 2014, Syndicat de la Librairie Française, 2009, The City of Paris, 2013, Club Décibel Villes, 2013, Devin et al., 2014).

As shown, the duration of most pilots is between 1 and 6 months, the exceptions are Stockholm, Denmark and England where the 2-years length cover pilots in multiple commercial sectors and cities. OPHD initiative can come from the private sector, the public sector, a University or a consortium. As mentioned before, the implementation approach in NYC includes incentives, while in European cities it mainly seeks the relaxation of access restrictions. It is noteworthy that every pilot has an articulated stakeholders' engagement program. The schemes implemented include staffed OPHD in every case, in the case of NYC and Denmark unassisted OPHD were tried, and in the case of NYC large traffic generators were also targeted. In general, the commercial sectors participating are food services, food retail, clothing retail, and pharmacies. Three pilots have been successful in initiating a permanent OPHD program (NYC, Paris and Barcelona), two others served as basis for further pilots (London 2012 and NYC 2003), and one of them was not completed (Denmark), two are currently ongoing (London 2013, Stockholm 2015).

In terms of assessment methods, all of the pilots included a set of interviews and surveys to participating receivers and carriers, economic analyses to evaluate the potential of the initiative and comprehensive noise measurements. The use of GPS measures is not always explicit, but it is safe to assume that most pilots used GPS. The use of network models to estimate savings on other road users was only reported for NYC. Table 2 provides a summary of the savings reported through these assessments.

\section{Table 2: Summary of pilots' results}

\begin{tabular}{|c|c|c|c|c|c|}
\hline Pilot test & New York City & London & Denmark & Paris & $\begin{array}{c}\text { Stockholm } \\
\text { (preliminary } \\
\text { results) }\end{array}$ \\
\hline $\begin{array}{l}\text { Travel time } \\
\text { savings }\end{array}$ & $\begin{array}{l}-1.25 \mathrm{~h} \text { in a } 10 \\
\text { miles tour }\end{array}$ & $\begin{array}{l}-38-55 \% \\
-1 \text { h per trip }\end{array}$ & $\begin{array}{l}-8 \text { to } 10 \% \text { less } \\
\text { vehicle miles }\end{array}$ & $-50-56 \%$ & $50-60 \%$ \\
\hline $\begin{array}{l}\text { Service time } \\
\text { savings }\end{array}$ & - Up to 1 hour & n.a. & $\begin{array}{l}-9-17 \% \text { overall } \\
\text { time savings }\end{array}$ & $\begin{array}{l}-27-61 \% \text { overall } \\
\text { time savings }\end{array}$ & n.a. \\
\hline $\begin{array}{l}\text { Environmental } \\
\text { impacts }\end{array}$ & $\begin{array}{l}\text { - } \mathrm{CO} 2 \text { reduction: } \\
20-75 \%\end{array}$ & $\begin{array}{l}\text { - } \mathrm{CO} 2 \text { reduction: } \\
48-62 \%\end{array}$ & $\begin{array}{l}\text { - } \mathrm{CO} 2 \text { reduction: } \\
7 \% \text { for beverages } \\
\text { distribution }\end{array}$ & $\begin{array}{l}-\mathrm{CO} 2 \text { reduction } \\
36-40 \%\end{array}$ & $\begin{array}{l}\text { - } \mathrm{CO} 2 \text { reduction } \\
20-40 \% \text { based on } \\
\text { fuel reduction }\end{array}$ \\
\hline $\begin{array}{c}\text { Noise } \\
\text { assessment/ } \\
\text { complaints }\end{array}$ & - No complaints & $\begin{array}{l}\text { - No complaints } \\
\text { - Curtains reduce } \\
\text { noise } 8-10 \mathrm{~dB}\end{array}$ & $\begin{array}{l}\text { - Some safety } \\
\text { issues } \\
\text { - No noise } \\
\text { complaints for } \\
\text { most pilots }\end{array}$ & $\begin{array}{l}\text { - } 1 \text { complaint } \\
\text { over unloading } \\
\text { area } \\
\text { - OPHD done } \\
\text { under } 60 \mathrm{~dB}\end{array}$ & $\begin{array}{l}\text { - No complaints } \\
\text { - Noise logged } \\
\text { for evaluation }\end{array}$ \\
\hline
\end{tabular}


Sources: Authors' interpretation from results in (Holguín-Veras, 2006, Holguín-Veras et al., 2013, Department for Transport, 2011, Freight Transport Association, 2008, Noise Abatement Society, 2012, Transport for London, 2012b, Transport for London, 2015, Re-timing Deliveries Consortium, 2015, Baster H. et al., 2014, Kolstrup K. et al., 2014, Trafikstyrelsen and Vaeksthus, 2014, Syndicat de la Librairie Française, 2009, The City of Paris, 2013, Club Décibel Villes, 2013, Devin et al., 2014).

Although the different pilots measure performance in different metrics, it is possible to make a broad comparison. As shown, savings in travel time are close to 1 hour per tour in NYC and London, and about $50 \%$ for Paris. Some additional time savings can be accrued from service time, though these are not always measured independently. Environmental savings range between 7 and 75\%; and noise impacts are in general well managed through technology and training.

As a complement to the synthesis, one representative from each pilot was interviewed to inquire about success factors, challenges faced, probable reasons for failures, and other information that can be instrumental for future successful pilots. In total, five interviews were completed, one with a representative from the NYC Department of Transport, one with a representative from Transport for London to discuss the results from the pilots of the Retiming Program in London, another one with a representative from the Danish Transport Agency (Trafikstyrelsen), one with a representative from Certibruit the organization in charge of OPHD in Paris, and one with a representative from the Stockholm pilot. A summary of the results from the interviews is presented in Table 3. 
Table 3: Summary of learning points from the pilots

\begin{tabular}{|c|c|c|c|c|c|c|}
\hline \multicolumn{2}{|l|}{ City } & NYC & London & Denmark & Paris & Stockholm \\
\hline \multicolumn{2}{|c|}{ Origin } & Research project & $\begin{array}{c}\text { Olympic Games } \\
2012 \\
\end{array}$ & Operators' interest & $\begin{array}{c}\text { Public sectors' } \\
\text { interest }\end{array}$ & Research project \\
\hline \multirow{4}{*}{ 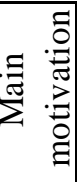 } & Congestion & $\checkmark$ & $\checkmark$ & & $\checkmark$ & $\checkmark$ \\
\hline & Economy & $\checkmark$ & & & $\checkmark$ & $\checkmark$ \\
\hline & Safety & & $\checkmark$ & & & \\
\hline & $\mathrm{CO} 2$ reduction & & $\checkmark$ & $\checkmark$ & $\checkmark$ & \\
\hline \multirow{8}{*}{ 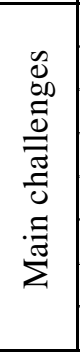 } & Convincing parties to try & $\checkmark$ & $\checkmark$ & $\checkmark$ & $\checkmark$ & \\
\hline & Engage municipalities & & & & $\checkmark$ & \\
\hline & Engage carriers: invest on low & & & $\checkmark$ & $\checkmark$ & \\
\hline & Coordinate receivers and carriers & $\checkmark$ & & & $\checkmark$ & $\checkmark$ \\
\hline & Make business case & $\checkmark$ & & & & \\
\hline & Control noise & & & $\checkmark$ & & $\checkmark$ \\
\hline & Residents expectations & & $\checkmark$ & & & \\
\hline & Ensure resources & & $\checkmark$ & & & $\checkmark$ \\
\hline \multirow{6}{*}{\multicolumn{2}{|c|}{ Main lessons and recommendation }} & $\begin{array}{l}\text { Strong Industry } \\
\text { Advisory Group }\end{array}$ & $\begin{array}{l}\text { Need of a set of } \\
\text { approved standards }\end{array}$ & Engage receivers & $\begin{array}{l}\text { Need of a set of } \\
\text { approved standards }\end{array}$ & $\begin{array}{l}\text { Need of a set of } \\
\text { approved standards }\end{array}$ \\
\hline & & $\begin{array}{l}\text { Business } \\
\text { associations support }\end{array}$ & OPHD are possible & $\begin{array}{l}\text { Incentives for } \\
\text { equipment }\end{array}$ & $\begin{array}{l}\text { Collaboration (city } \\
\text { and also site-by-site) }\end{array}$ & $\begin{array}{l}\text { Collaboration (city } \\
\text { and also site-by-site) }\end{array}$ \\
\hline & & $\begin{array}{l}\text { High level officials } \\
\text { support }\end{array}$ & $\begin{array}{l}\text { Collaboration (city } \\
\text { and also site-by-site) }\end{array}$ & $\begin{array}{l}\text { OPHD- } \\
\text { electrification go } \\
\text { together }\end{array}$ & $\begin{array}{l}\text { Incentives for } \\
\text { equipment }\end{array}$ & $\begin{array}{l}\text { Engage carriers, } \\
\text { receivers, local } \\
\text { community and } \\
\text { enforcement } \\
\text { authority }\end{array}$ \\
\hline & & Market the program & $\begin{array}{l}\text { Neutral party to } \\
\text { facilitate } \\
\text { stakeholders } \\
\text { meetings }\end{array}$ & $\begin{array}{l}\text { Be willing to handle } \\
\text { complaints }\end{array}$ & $\begin{array}{l}\text { Engage carriers, } \\
\text { receivers, local } \\
\text { community and } \\
\text { enforcement } \\
\text { authority }\end{array}$ & $\begin{array}{l}\text { Document and share } \\
\text { good practices }\end{array}$ \\
\hline & & $\begin{array}{l}\text { Iconic business } \\
\text { support }\end{array}$ & $\begin{array}{l}\text { Pilots for multiple } \\
\text { industries }\end{array}$ & & $\begin{array}{l}\text { Document and share } \\
\text { good practices }\end{array}$ & $\begin{array}{l}\text { Invest on low noise } \\
\text { technology research }\end{array}$ \\
\hline & & Make business case & Make business case & & $\begin{array}{l}\text { Invest on low noise } \\
\text { technology research }\end{array}$ & \\
\hline \multicolumn{2}{|c|}{ Pilot success (1: low, 10: high) } & 9 & 9 & 3 & 9 & pending \\
\hline \multicolumn{2}{|c|}{ Is OPHD part of City's plan? } & Yes & Yes & No & Yes & Yes \\
\hline
\end{tabular}

Source: Authors interpretation from interviews 
The results show clear contrasts in some aspects and major similarities in others. In the case of NYC, the OPHD initiative started as a way to counter the increasing congestion and help local businesses, in London the initiative was intended to alleviate congestion but also to improve air quality and safety (i.e., decrease conflicts between trucks and bikers), and in the case of Denmark the project initiated with the objective of reducing $\mathrm{CO} 2$ emissions. In London and Denmark the public sector played a role as coordinator and leader, in NYC Universities proposed the initiative and in Paris the organization Certibruit took the lead. In Stockholm, the initiative came from the public sector and the University was the coordinator and leader. The intention was to improve transport efficiency and to investigate new technology for noise reduction in city distribution.

In general, the challenges faced by the five cities are similar, with the top ones being the need to convince participants to try the concept (in particular receivers to accept OPHD and carriers to invest in low noise technology), and match receivers and carriers because carriers require a minimum number of receivers in the program to make the OPHD tour profitable. Other challenges include engage local municipalities, making a sound business case and controlling the noise (as well as the residents' expectations).

In terms of the success of the pilots, while in NYC, London, and Paris the pilots were considered as very successful (9/10), in Denmark the pilot was not considered as a success (3/10). In NYC, the success of the project is partly attributed to the strength of the Industry Advisory Group, the business support, the Business Improvement Districts support, and the support from the high level officials. In London, the success is mainly attributed to a successful set of standards (Code of Practice) for participants, and a strong collaboration both at the city-level and at the local level (i.e., for each site all involved stakeholders should cooperate). In Paris, the solid engagement of a large carrier and a supermarket chain were key. In Denmark, the low success was mainly attributed to the receivers' lack of interest, their reluctance to pay for extra receiving staff during OPH and the low willingness to purchase low-noise technology from carriers.

According to the representatives interviewed, the main benefits perceived from OPHD are lower operation costs for carriers, higher reliability of deliveries, less environmental impacts, less stress, and an increase in safety. In NYC, the decrease in parking fines for carriers and the opportunity to use space on the curb for receivers were also perceived as benefits from the program. All the cities observed that following low-noise procedures and using low-noise equipment (PIEK certified) could make OPHD comply with low-noise regulation (in NYC and London no noise complaints were filed). In Stockholm regulations are temporarily released so that low-noise trucks are allowed into the city during night. In the pilot, noise is measured in different ways to verify the effects of noise reduction actions.

In Denmark, although the public sector offered co-funding to invest on low noise technology for carriers, they used only $60 \%$ of these funds, reflecting a low willingness to invest to do OPHD. In NYC, a monetary incentive was offered to some of the receivers in the pilots, public recognition and use of loading zones for commercial purposes has been offered to receivers that continue in the program. In London, no incentives were provided to the participants, but to maximize behavior change the future strategy may require a combination of incentives and regulatory changes.

Although in every case there are some important learning points, the success of the pilots were heterogeneous. In Denmark, they did not produce results to consider a long term implementation of OPHD. However, NYC confirmed its commitment to OPHD as one of the freight-related initiatives in the plan for the city One NYC (City of New York, 2015), and the Federal Highway Administration and the Environmental Protection Agency decided to foster the implementation of OPHD in mid-size cities (Federal Highway Administration, 2012). Similarly, the City of Paris included OPHD in their plan as one of the measures to 
reach sustainable urban logistics (The City of Paris, 2013). In London the Out-of-hours Delivery Program concentrate significant political focus, and there is a new set of pilots in progress by the time this report was written. The City of Stockholm is optimistic about the benefits of OPHD, but the conditions are being assessed in the ongoing pilot.

The interviews and the literature reviewed have revealed a number of challenges when implementing OPHD, as well as some potential solutions. These findings are summarized in Table 4.

Table 4: Summary of challenges and potential solutions

\begin{tabular}{|c|c|}
\hline Challenges & Solutions \\
\hline Noise & $\begin{array}{l}\rightarrow \text { Low noise technology (e.g., engines, roller cages, floors) } \\
\rightarrow \text { Create a guide and a set of standards } \\
\rightarrow \text { Train the drivers on low noise practices } \\
\rightarrow \text { Create a noise measurement program }\end{array}$ \\
\hline Access restrictions & $\begin{array}{l}\rightarrow \text { Discuss with local authorities and communities } \\
\rightarrow \text { Initiate pilots } \\
\rightarrow \text { Habilitate complaints line } \\
\rightarrow \text { Gain high level officials support } \\
\rightarrow \text { Create awareness which restrictions are and are not in place } \\
\rightarrow \text { Coordinate restrictions across municipalities }\end{array}$ \\
\hline Receivers participation & $\begin{array}{l}\rightarrow \text { Make the business case } \\
\rightarrow \text { Provide incentives (e.g., public recognition) } \\
\rightarrow \text { Implement unassisted OPHD } \\
\rightarrow \text { Target the right sectors } \\
\rightarrow \text { Market the program }\end{array}$ \\
\hline Carriers participation & $\begin{array}{l}\rightarrow \text { Initiate pilots and assess benefits } \\
\rightarrow \text { Obtain funds to subsidize changes in technology } \\
\rightarrow \text { Public recognition } \\
\rightarrow \text { Market the program }\end{array}$ \\
\hline
\end{tabular}

\section{The importance of stakeholders engagement}

OPHD programs are primarily implemented in large and congested cities where the benefits from shifting a share of daily traffic to the OPH can offset the costs that the program entails. This also means that OPHD are typically implemented in cities with a large number of stakeholders affected by freight activity. The literature review and the experience with previous OPHD pilots show that the key challenges are often associated with one or several opposing stakeholders.

In the case of congestion pricing schemes, the inefficiency of the program was explained by the opposition of receivers, and the subsequent compliance to the receiver preferences from carriers and shippers who had to assume the congestion charges to avoid losing customers. In the Operation "Moondrop" in London, Churchill (1970) identified lack of communication and opposition from receivers as the main challenges and possible reasons for the failure of the program. In England and Denmark, the main challenges have been associated with the opposition from local boroughs and residents (mainly because of potential noise impacts); and with a lack of commitment from the receiving establishment's local managers (Department for Transport, 2011, Kolstrup K. et al., 2014). Although the pilot tests have been successful in proving that OPHD can comply 
with low noise standards when using appropriate technology solutions and training drivers, the numerous jurisdictions present in each metropolitan area and their autonomy to establish access restrictions remains a key challenge.

Overcoming these challenges requires an articulated stakeholder engagement program that takes into account every stakeholder interests and requirements, and plans resources and information accordingly (Lindholm, 2012). The pilots involved numerous stakeholders, such as industry representatives (receivers, shippers, carriers, firms with integrated operations, and logistics providers), Business Improvement Districts, Boroughs representatives, City representatives, Region Authority representatives, universities and research organizations, organizations concerned with noise, real state owners, transport associations, retailers associations, drivers and their unions, and local store managers, among others. Although in some case several stakeholders belong to the same organization, they can have different interests and needs, and not taking them into account could hamper the success of the program. Given this multiplicity of stakeholders, getting in contact with them and the mechanism to engage them is not trivial.

The experience with the pilots can provide some insight on how to engage them in an appropriate way. Holguín Veras et al. (2013) highlight the importance of having a person in the Public Sector Authority that is the point of contact and is in charge of freight issues. The authors also suggest the creation of an Industry Advisory Group (IAG) where the various commercial sectors represented can provide timely feedback, and complement these meetings with targeted outreach efforts to involve other stakeholders that are not part of the IAG. The existence of Business Improvement Districts in NYC have been an important element to promote OPHD as a business friendly initiative, and a channel to gain the support from local retailers. The experience in London and Paris have also shown the importance of the coordination across multiple municipalities, between multiple authorities, and between local boroughs within a municipality (Freight Transport Association, 2008, Club Décibel Villes, 2013). In every case, the pilots have been valuable to anticipate potential problems and conflicts, to demonstrate potential benefits from OPHD and to gain stakeholders' support.

\section{Conclusion}

The review presented in this paper shows that shifting freight traffic to the OPH has been a popular initiative considered throughout the years by both the private and the public sector, and there seems to be a consensus on the benefits that these programs could bring about. A key aspect when implementing Off-Peak Hour Deliveries (OPHD) is understanding the decision process leading to delivery-time. Although there are multiple delivery arrangements, the literature shows that receivers' and the public sector's constraints prevail when defining the time-windows for deliveries (often overlapping with peak-hours), while carriers' operational decisions dominate the specific delivery-time within those time-windows. Accordingly, OPHD implementation approaches targeting a relaxation of receivers and the public sectors' constraints have showed better results, than the ones targeting carriers.

Another aspect that facilitates successful OPHD program is the type of schemes. Past experience revealed that the high cost of staffed OPHD led to unsustainable programs that were usually not pursued, while unassisted deliveries aided by technology and trust links between carriers and receivers led to successful programs. The case of OPHD at large traffic generators is interesting because despite its big potential and suitability, a limited amount of literature was found describing this practice. 
The literature studied and the interviews show that OPHD are suitable to tackle common urban challenges and bring about positive outcomes, e.g., travel time savings, fuel savings, environmental savings, and stakeholders' satisfaction. This study also identified a number of challenges that need to be considered and addressed to ensure the success of OPHD, such as decreasing noise impacts, relaxing access and loading/unloading restrictions, and ensuring stakeholder engagement. The experience in different cities suggest elements to address these issues, such as:

(i) Introducing low noise technology, guides and standards, train the drivers on low noise practices, and create a noise measurement program to address noise issues

(ii) Discuss with local authorities and communities, initiate pilots, gain high levels officials support, identify and create awareness of existing and non-existing access restrictions, and coordinate restrictions across municipalities.

(iii) Develop the OPHD business case and market the program, design incentives program, foster unassisted and large traffic generators OPHD, and target the right industry sectors to encourage receivers' voluntary participation.

(iv) Initiate pilots and assess benefits, obtain funds to subsidize changes in technology, provide public recognition, and market the program to encourage carriers' participation

(v) Design an articulated stakeholder engagement program that includes the different stakeholders, such as receivers, shippers, carriers, local boroughs, residents, local store managers, business improvement districts, real state owners, local authorities and communities, and high level officials.

There is a growing body of literature discussing low noise technologies and practices that are crucial for the success of OPHD programs. However, the scope of this paper was limited to the implementation of OPHD programs, and does not discuss in detail low noise bibliography, which could be the subject of a different review paper. Although the point of view of other stakeholders, such as receivers and carriers, is of great importance for OPHD, this paper focused on interviews to representatives from the organization coordinating the programs due to space and time constraints. For an example of analyses of other stakeholders perspectives, see (Brom et al., 2011).

In essence, this review shows that significant progress has been made in this domain in the last decade. There is a handful of cities that have identified key factors to overcome the challenges of OPHD, and are considering this initiative as part of their Strategic Development Plans. In these cities, the body of research and the pilots have been successful to convince the transportation community, the key stakeholders and the decision makers that OPHD programs can assist in the quest of reaching more sustainable and efficient transportation systems.

\section{References}

ALLEN, J., ANDERSON, S., BROWNE, M. \& JONES, P. 2000. A Framework for Considering Policies to Encourage Sustainable Urban Freight Traffic and Goods/Service Flows. London, England: University of Westminster.

ALLEN, J., BROWNE, M., CHERRETT, T. \& MCLEOD, F. 2008. Review of UK urban freight studies. Green Logistics project, Universities of Westminster and Southampton. London: Universities of Westminster and Southampton.

BASTER H., BENTZEN K., BENTZEN L. \& STIE LAUGESEN M. 2014. Supporting electric vehicles in freight transport in Copenhagen Municipality. In: PROGRAMME, T. I. I. N. S. R. (ed.) North Sea 
Region Electric Monility Network e-Mobility NSR. Aalborg, DK: FDT Association of Danish Transport and Logistics Centres, Hamburg University of Applied Sciences.

BEIJING TRAFFIC MANAGEMENT BUREAU. 2014. Delivery Time Restrictions [Online]. Beijing, China. Available: http://zhengwu.beijing.gov.cn/gzdt/gggs/t1348811.htm [Accessed July 22th, 2014].

BERECHMAN, J. \& PAASWELL, R. E. 2005. Evaluation, prioritization and selection of transportation investment projects in New York City. Transportation, 32, 223-249.

BROADDUS, A., BROWNE, M. \& ALLEN, J. 2015. Sustainable Freight: Impacts of the London Congestion Charge and Low Emissions Zone. Transportation Research Board Annual Conference. Washington, D.C.

BROM, M. A., HOLGUÍN-VERAS, J. \& HODGE, S. 2011. Off-Hour Deliveries in Manhattan, New York City: Experiences of Pilot Test Participants. Transportation Research Record, 2238, 77-85.

BROWNE, M., ALLEN, J., ANDERSON, S. \& WOODBURN, A. 2006. Night-Time Delivery Restrictions: A Review. In: TANIGUCHI, E. \& THOMPSON, R. (eds.) Recent Advances in City Logistics. Elsevier.

BROWNE, M., ALLEN, J. \& ATTLASSY, M. 2007. Comparing freight transport strategies and measures in London and Paris. International Journal of Logistics Research and Applications, 10, 205-219.

BROWNE, M., ALLEN, J., NEMOTO, T., VISSER, J. \& WILD, D. 2008. City Access Restrictions and the Implications for Goods Deliveries. In: TANIGUCHI, E. \& THOMPSON, R. G. (eds.) Innovations in city logistics. Taniguchi, Eiichi and Thompson, Russell G. ed. New York, NY: Nova Science Publishers.

BROWNE, M., ALlEN, J., WAINWRIGHT, I., PALMER, A. \& WILliAMS, I. 2014. London 2012: changing delivery patterns in response to the impact of the Games on traffic flows. International Journal of Urban Sciences, 18, 244-261.

CAMBRIDGE SYSTEMATICS INC. 1988. Urban Gridlock Study: Technical Report. Sacramento, USA: California Department of Transportation.

CAMPBELL, J. F. 1995. Peak Period Large Truck Restrictions and a Shift to Off-Peak Operations: Impact on Truck Emission and Performance. Journal of Business Logistics, 16, $227-247$.

CHANGSHA BUREAU OF PUBLIC SECURITY. 2013. Announcement about Freight Vehicles Ban in Certain Areas and Routes [Online]. Changsha, China. Available: http://www.changsha.gov.cn/xxgk/gfxwj/sqzz/sgajjzd/201303/t20130313_437903.html [Accessed July 22th, 2014].

CHERretT, T., ALlEn, J., MCleOD, F., MAYNARD, S., HICKFORD, A. \& BROWNE, M. 2012. Understanding Urban Freight Activity - Key Issues for Freight Planning. Journal of Tranport Geography, 24, 22-32.

CHURCHILL, J. D. C. Operation "MoonDrop" : An Experiment in out of Hours Goods Delivery. Proceedings of the 3rd Technology Assessment Review, 1970 Paris, France. Organization for Economic Cooperation and Development, 135-140.

CITY OF NEW YORK 2015. One New York: The Plan for a Strong and Just City.

CLUB DÉCIBEL VILLES. 2013. Comment livrer silencieusement la nuit? La solution du label Certibruit [Online]. Paris: Certibruit. Available: http://www.bruit.fr/comment-livrer-silencieusement-la-nuit-lasolution-du-label-certibruit.html?pop=1\&print=1\&tmpl=component [Accessed 18/03/2015 2015].

DE PALMA, A., KILANI, M. \& LINDSEY, R. 2005. Congestion Pricing on a Road Network: A Study Using the Dynamic Equilibrium Simulator METROPOLIS. Transportation Research Part A: Policy and Practice, 39, 588-611.

DEPARTMENT FOR TRANSPORT 2011. Quiet Deliveries Demonstration Scheme - Case Studies. London: Department for Transport.

DEVIN, E., EL MOUSSATI, H., MOIZAN, V., CAVALIER, G. \& BONNAL, J. M. 2014. Livre blanc: Les livraisons de nuit en logistique urbaine. In: SAS, C. F. (ed.). Paris, France.

DOMÍNGUEZ, A., HOLGUÍN-VERAS, J., IBEAS, Á. \& DELL'OLIO, L. 2012. Receivers' Response to New Urban Freight Policies. Procedia-Social and Behavioral Sciences, 54, 886-896. 
FEDERAL HIGHWAY ADMINISTRATION. 2012. Federal Grant Opportunity Request for Applications (RFA): Off Hours Freight Delivery Pilot Project [Online]. Available: http://apply07.grants.gov/apply/opportunities/instructions/oppDTFH61-12-RA-00016-cfda20.200cidDTFH61-12-RA-00016-instructions.pdf [Accessed July 1, 2012].

FREIGHT TRANSPORT ASSOCIATION. The London Lorry Ban: Exempt Route Network Study [Online]. London: $\quad$ FTA. Available: http://www.fta.co.uk/export/sites/fta/_galleries/downloads/lorry_ban_case_study.pdf 05/02/2015 2015].

FREIGHT TRANSPORT ASSOCIATION. 2008. Delivering the goods: A toolkit for improving night-time deliveries [Online]. Available: http://www.fta.co.uk/export/sites/fta/_galleries/downloads/delivery_improvement.pdf [Accessed].

FREIGHT TRANSPORT ASSOCIATION. Managing Deliveries and Servicing During the Olympic Games. FTA Conference, 11 May 2011 London.

GANG, C. 2009. Politics of China's environmental protection: problems and progress, World Scientific.

GOEVAERS, R. PIEK: Low noise solutions Night time deliveries. Sustainable Urban Goods logistics Achieved by Regional and local policies (SUGAR), 2010 Barcelona, Spain.

GOEVAERS, R. 2011. PIEK: Low Noise Equipment, Off Peak Hours Transport. 91s Annual Meeting of the Transportation Research Board. Washington, D.C. .

GREENZEBACK, L., REILLY, W., ROBERTS, P. O. \& STOWERS, J. R. 1991. Urban freeway gridlock study: decreasing the effects of large trucks on peak-period urban freeway congestion. Transportation Research Record, 1256, 16-26.

HOLGUÍN-VERAS, J. 2006. Potential for Off-Peak Freight Deliveries to Congested Urban Areas Albany, NY: Rensselaer Polytechnic Institute.

HOLGUÍN-VERAS, J. 2008. Necessary Conditions for Off-Hour Deliveries and the Effectiveness of Urban Freight Road Pricing and Alternative Financial Policies in Competitive Markets. Transportation Research Part A: Policy and Practice, 42, 392-413.

HOLGUÍN-VERAS, J. \& AROS-VERA, F. 2014. Self-Supported Freight Demand Management: Pricing and Incentives. EURO Journal on Transportation and Logistics, 3, 1-24.

HOLGUÍN-VERAS, J., JALLER, M., AMAYA, J., WANG, C., GONZÁLEZ-CALDERÓN, C., SÁNCHEZDÍAZ, I., BROWNE, M., WOJTOWICZ, J., HODGE, S., RHODES, E. \& HAAKE, D. Public Sector Freight Strategies in Metropolitan Areas I: Governance, Supply Side, and Traffic Operations. Transportation Research Board 93rd Annual Meeting, 2014a Washington D.C.: Transportation Research Board.

HOLGUÍN-VERAS, J., MARQUIS, R. \& BROM, M. Economic Impacts of Staffed and Unassisted off-Hour Deliveries in New York City. Procedia - Social and Behavioral Sciences, 2012. 34-46.

HOLGUÍN-VERAS, J., ÖZBAY, K. \& CERREÑO, A. 2005a. Evaluation Study of Port Authority of New York and New Jersey's Time of Day Pricing Initiative: Final Report. Trenton, N. J.: New Jersey Dept. of Transportation.

HOLGUÍN-VERAS, J., OZBAY, K., KORNHAUSER, A. L., BROM, M., IYER, S., YUSHIMITO, W., UKKUSURI, S., ALLEN, B. \& SILAS, M. 2011. Overall Impacts of Off-Hour Delivery Programs in the New York City Metropolitan Area. Transportation Research Record, 2238, 68-76.

HOLGUÍN-VERAS, J., POLIMENI, J., CRUZ, B., XU, N., LIST, G., NORDSTROM, J. \& HADDOCK, J. 2005b. Off-Peak Freight Deliveries: Challenges and Stakeholders' Perceptions. Transportation Research Record, 1906, 42-48.

HOLGUÍN-VERAS, J., SÁNCHEZ-DÍAZ, I., JALLER, M., AROS-VERA, F., CAMPBELL, S., WANG, C. \& HODGE, S. 2014b. Off-Hour Delivery Programs. City Logistics: Mapping The Future.

HOLGUÍN-VERAS, J., SILAS, M. A., POLIMENI, J. \& CRUZ, B. 2007. An Investigation on the Effectiveness of Joint Receiver-Carrier Policies to Increase Truck Traffic in the Off-Peak Hours: Part I: The Behaviors of Receivers. Networks and Spatial Economics, 7, 277-295. 
HOlguíN-VERAS, J., WANG, C., BROWNE, M., HODGE, S. D. \& WOJTOWICZ, J. 2014c. The New York City Off-Hour Delivery Project: Lessons for City Logistics. Procedia-Social and Behavioral Sciences.

HOLGUÍN-VERAS, J., WANG, C., SÁNCHEZ-DÍAZ, I., CAMPBELL, S., HODGE, S. D., JALLER, M. \& WOJTOWICZ, J. 2015. Fostering Unassisted Off-Hour Deliveries: The Role of Incentives. Tranportation Research Part A: Policy and Practice, (in print).

HOLGUÍN-VERAS, J., WANG, Q., XU, N., OZBAY, K., CETIN, M. \& POLIMENI, J. 2006. Impacts of Time of Day Pricing on the Behavior of Freight Carriers in a Congested Urban Area: Implications to Road Pricing. Transportation Research Part A: Policy and Practice, 40, 744-766.

HOLGUÍN-VERAS, J., WOJTOWICZ, J. M., WANG, C., JALLER, M., BAN, X. J., AROS-VERA, F., CAMPBELL, S., YANG, X., SANCHEZ-DIAZ, I., AMAYA, J., GONZÁLEZ-CALDERÓN, C., MARQUIS, R., HODGE, S. D., MAGUIRE, T., MARSICO, M., ZHANG, S., ROTHBARD, S., OZBAY, K., MORGUL, E. F., IYER, S., XIE, K. \& OZGUVEN, E. E. 2013. Integrative Freight Demand Management in the New York City Metropolitan Area: Implementation Phase. Rensselaer Polytechnic Institute, New York City Department of Transportation, Rutgers University.

HOLGUÍN VERAS, J., AMAYA-LEAL, J., WOJTOWICZ, J., JALLER, M., GONZÁLEZ-CALDERÓN, C., SÁNCHEZ-DÍAZ, I., WANG, X., HAAKE, D., RHODES, S., HODGE, S. D., FRAZIER, R. J., NICK, M. K., DACK, J., CASINELLI, L. \& BROWNE, M. 2015. NCFRP 33 Improving Freight System Performance in Metropolitan Areas. National Cooperative Freight Research Program. Washington, D.C.: Transportation Research Board.

HOLGUÍN VERAS, J., WANG, C., HODGE, S., WOJTOWICZ, J., ROTHBARD, S. \& BROWNE, M. 2013. The New York City Off-Hour Delivery Project: Lessons for City Logistics. In: TANIGUCHI, E. \& THOMPSON, R. G. (eds.) Innovations in City Logistics. Elsevier.

INSTITUT CERDÁ 2010. Logística urbana: ciudad y mercancías, Barcelona, Spain, Marge Books.

JALLER, M., WANG, X. \& HOLGUÍN-VERAS, J. 2014. Large Traffic Generators: Opportunities for City Logistics Initiatives. Journal of Transport and Land Use, (in print).

KOLSTRUP K., HENRIQUES M., HANSEN H. \& ZOEGA F. 2014. Distribution i Ydertimerne. Incentive, Teknologisk Institut.

LAMMGÅRD, C. \& BROWNE, M. 2012. Night-time deliveries: Supply chain dream or policy nightmare. Logistics Research Network Annual Conference. Cranfield, UK.

LINDHOLM, M. 2012. Enabling Sustainable Development of Urban Freight from a Local Authority Perspective. $\mathrm{PhD}$, Chalmers University of Technology.

LONDON COUNCILS. 2010. About the London Lorry Control Scheme [Online]. London, UK. Available: http://www.londoncouncils.gov.uk/services/london-lorry-control/about-llcs [Accessed 05/02/2015 2015].

MUÑUZURI, J., CORTÉS, P., GUADIX, J. \& ONIEVA, L. 2012. City logistics in Spain: Why it might never work. Cities, 29, 133-141.

NICHES. 2008. Innovative Approaches in City Logistics: Inner-City Night Delivery [Online]. Available: http://www.nichestransport.org/fileadmin/archive/Deliverables/D4.3b 5.8 b PolicyNotes/14683 pn7 night delivery o k_low.pdf [Accessed March 26 2010].

NOEL, E. C. 1983. Night Delivery: Institutional Restraints. Journal of Urban Planning and Development, 109, 44-49.

NOEL, E. C., CRIMMINS, S. H., MYERS, N. K. \& ROSS, P. 1980. A Survey of Off-Hours Delivery. ITE Journal, 18-23.

NOISE ABATEMENT SOCIETY. 2012. Out-of-hours deliveries to be encouraged during London 2012 Olympic and Paralympic Games [Online]. Available: http://noiseabatementsociety.com/2012/04/26/london2012/\#sthash.5A93mUeP.dpuf [Accessed].

OGDEN, K. W. 1992. Urban Goods Movement: A Guide to Policy and Planning, Brookfield, VT, Ashgate Publishing Company. 
OLYMPIC DELIVERY AUTHORITY. 2010. On Time: London 2012 - Olympic Route Network and Paralympic Route Network (London: Olympic Delivery Authority) [Online]. Available: http://www.london2012.com/publications/olympic-route-network-and-paralympic-routenetwork.php [Accessed 20 September 2011].

ORGANIZATION FOR ENVIRONMENTAL GROWTH INC. \& FEDERAL HIGHWAY ADMINISTRATION 1979. Requirements and specifications for off-hours delivery. Washington D.C.: National Technical Information Service.

PIERPASS. 2007. PierPASS OffPeak Information

[Online]. Available: http://www.pierpass.org/offpeak-information/ [Accessed October 10, 2007].

QUAK, H. J. \& DE KOSTER, M. B. M. 2007. Exploring Retailers' Sensitivity to Local Sustainability Policies. Journal of Operations Management, 25, 1103-1122.

RE-TIMING DELIVERIES CONSORTIUM 2015. Getting the timing right. In: LONDON, T. F. (ed.). London.

SATHAYE, N., HARLEY, R. \& MADANAT, S. 2010. Unintended Environmental Impacts of Nighttime Freight Logistics Activities. Transportation Research Part A: Policy and Practice, 44, 642-659.

SCHOEMAKER, J., ALLEN, J., HUSCHEBEK, M. \& MONIGL, J. 2006. Quantification of urban freight transport effects I. BESTUFS Consortium, www. bestufs. net. NEA, University of Westminster, PTV, Transman.

SHENZHEN BUREAU OF PUBLIC SECURITY. 2013. Announcement about Truck Routes and Banned Areas [Online]. Shenzhen, China. Available: http://www.szga.gov.cn/NEWWEB/ZWGK/QT/GSGG/201307/t20130718_54558.htm [Accessed July 22, 2014].

SYNDICAT DE LA LIBRAIRIE FRANÇAISE. 2009. La livraison de nuit à Paris [Online]. Paris: La Rédaction. Available: http://www.syndicat-librairie.fr/la_livraison_de_nuit_a_paris [Accessed 10/02/2015 2015].

THE CITY OF PARIS 2013. Charte en faveur d'une logistique urbaine durable. Paris: Mairie de Paris.

TRAFIKSTYRELSEN \& VAEKSTHUS 2014. 24T Transport. Copenhagen, DK.

TRANSPORT FOR LONDON 2012a. Quieter Out-of-hours Deliveries Trial Case Studies.

TRANSPORT FOR LONDON 2012b. Transport for London's Code of Practice for Quieter Out-of-hours Deliveries.

TRANSPORT FOR LONDON. 2012c. Travel in London: Report 5 [Online]. London. Available: http://www.tfl.gov.uk/assets/downloads/corporate/travel-in-london-report-5.pdf [Accessed 2012].

TRANSPORT FOR LONDON. 2015. Retiming \& out-of-hours deliveries [Online]. London. Available: https://www.tfl.gov.uk/info-for/freight/moving-freight-efficiently/retiming-and-out-of-hoursdeliveries [Accessed 23/05/2015 2015].

VICKREY, W. S. 1969. Congestion Theory and Transport Investment. The American Economic Review, 59, 251-260.

VILAIN, P. \& WOLFROM, P. 2000. Value Pricing and Freight Traffic: Issues and Industry Constraints in Shifting from Peak to Off-Peak Movements. Transportation Research Record, 1707, 64-72. 